American Journal of Applied Sciences 4 (12): 1084-1089, 2007

ISSN 1546-9239

(C) 2007 Science Publications

\title{
Contractor's Perception of the Use of Statistical Approach in the Tender Evaluation at the Public Works Department, Malaysia
}

\author{
Faridah Muhamad Halil \\ Faculty of Architecture, Planning and Surveying, 40450 University of Technology MARA, Malaysia
}

\begin{abstract}
Contractor selection is one of the main activities of clients. Without a proper and accurate method for selecting the most appropriate contractor, the performance of the project will be affected. The usage of statistical method is implemented by Public Works Department as a better tool for the selection of suitable contractor. This method would avoid a personal preference during selection of contractor for government project. Furthermore, this method will ensure the price submitted by the tenderer is reflective of the current market conditions. The statistical method uses mean, standard deviation and coefficient variation and this has been applied via a computer program based on Microsoft Excel for ease of calculation. Previously the contractor selection process is based on the lowest price or as compared to the Quantity Surveyor's estimate and this method exhibit an inherent weakness. Result from the survey questionnaire shows that the contractor agreed that the government has implemented a systematic approach using statistical method.
\end{abstract}

Key words: Contractor selection, new method of selection contractor and analysis of variance

\section{INTRODUCTION}

Previously, the Public Works Department had adopted a where a capable tenderer was selected from selection of a contractor is largely based on the comparison between the tender received against the departmental estimate as a method to select a capable tenderer. This dependence on the departmental estimate to select a capable tenderer sometimes may not be fair due to the probability of inaccuracy of the estimate. This inaccuracy may be due to insufficient information or calculation errors ${ }^{11}$.

To ensure that tender price is reasonable and in accordance to market price for tender acceptance, the Public Works Department introduced a method called the cut-off method. The cut-off price was based on a statistical method during tender to evaluate the bids submitted by the contractors. The tender price included the project cost estimated by the Department, i.e. departmental estimate. The cut-off method has been introduced at Public Works Department since 2002.

The new method of selecting a contractor proposed by PWD is to determine and endorse the most economical bid and the most suitable contractor for award. Utmost important is to avert project implementation failure due to the contractor's inability to undertake or complete the works. Therefore, a uniform set of guideline in selecting a contractor is essential to ensure that pricing and background of the bidder is thoroughly assessed and the best selected for award to ensure the successful implementation of the project.

New Method of Selection Contractor Implemented by Public Works Department (PWD): The new method implemented by PWD is statistic based called the Cut-Off method. This method is used to shortlist the tenderer for further evaluation and normally implemented after the tender opening. A computer program based on Microsoft Excel is employed in the calculation of cut-off price for tender verification.

The method employed in the computer program is based on the statistical mean, standard deviation, coefficient variation and frequency distribution.

The formula used as follows;

Cut-off price $=$ Mean -1.18 x Standard Deviation

Mean $=$ Average for all tender price including department estimate.

$\left(\sum \mathrm{X} / \mathrm{N}\right)$

Standard deviation $=\underline{\mathrm{N} \sum \mathrm{X} 2-\left(\sum \mathrm{X}\right) 2}$

$\mathrm{N} 2$

$\mathrm{X}=$ The total of tender price including department estimate

$\mathrm{N}=$ The total numbers of tender received including department estimate

$\mathrm{CV}=$ Standard deviation/ mean

All the formula above has been used for selection of contractor during evaluation of tender.

\section{MATERIALS AND METHODS}

The questionnaire survey was undertaken to determine the opinion from contractor regarding the current tender evaluation practices in the Malaysia construction industry. A nine page questionnaire, accompanied by a covering letter, was sent to the Senior and Middle Management level which have knowledge in tendering procedure. The questionnaire

Corresponding Author: $\quad$ Faridah Muhamad Halil, Faculty of Architecture, Planning and Surveying, 40450 University of Technology MARA, Malaysia 
design was based on a combination of an extensive review of the literature in this study area.

Sample of study: The sample of the study was based on Class 'A' Contractors in the Klang Valley area that were only involved in building works. The respondent targeted were Grade 7 contractors registered with CIDB. The contractor was selected due to their experience in the construction industry for effectiveness on questionnaire survey. A total of 300 questionnaires were sent to these respondents. The respondents selected are senior and middle management level with knowledge in tendering procedures.

Returns and analysis: Completed questionnaires were received from 42 respondents out of the 300 questionnaires sent for this survey. This $14 \%$ response is considered satisfactory for surveys of this type.

Non-response: Respondents who declined to participate in the survey, stated reasons such as 'lack of resources to deal with', 'organizational policy not to participate in this kind of surveys' and 'lack of interest'. Similar reasons might be the cause of non-response from the rest of the survey population.

Non-response in this case should not invalidate the outcome of the survey. Rather it does imply that the responses received are intrinsic interest, coming from a cross-section of willing participants. The number of comments on the questions indicated enthusiasm in those who did respond.

\section{RESULT AND DISCUSSION}

Reliability of instrument: The internal reliability of instrument (questionnaire) was assessed using Cronbach's Alpha $(\alpha)$. Cronbach's alpha is an index of realibility associated with the variation accounted for by the true score of the "underlying construct." Construct is the hypothetical variable that is being measured (Hatcher, 1994). Alpha's coefficient ranged in value from 0 to 1 . It is used to describe the realibility of the instrument for multi-point formatted scales (i.e, $1=$ very dissatisfied to $5=$ very satisfied). The higher the value, the more reliable the instrument is. Generally, the acceptable alpha $(\alpha)$ values considered for social science research purposes are above 0.65. In this particular study, the reliability of the 11 questions in Section D of the questionnaire was tested in its entirety with Cronbach's alpha. The alpha's coefficient of 0.740 concluded that the reliability of the instrument was high. Refer Table 1 below, show realibility statistics using Cronbach's alpha.
Table 1: Reliability Statistics

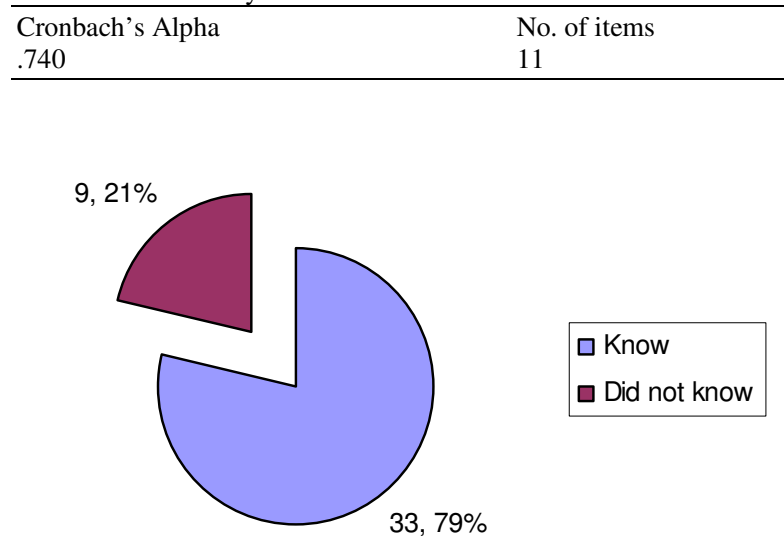

Fig. 1: Contractor know whether statistical (cut-off) method to be used in the tender evaluation

Contractor has been asked whether they know that statistical (cut-off) method is to be used in the tender evaluation: When asked whether they know that statistical (cut-off) method to be used in the tender evaluation, 33 of the contractors (79\%) indicated 'yes'. Only 9 contractors $(21 \%)$ did not know that statistical (cut-off) method is to be used in tender evaluation. Figure 1 shows the distribution of Contractor know whether statistical (cut-off) method to be used in the tender evaluation.

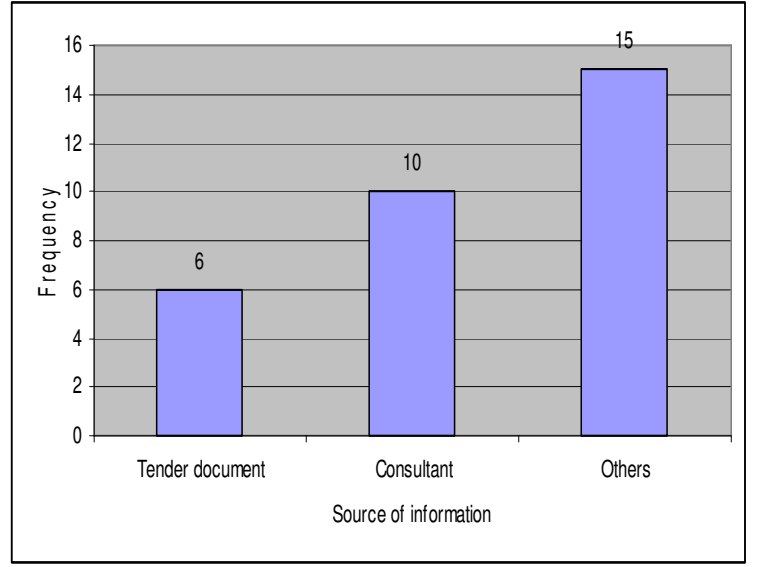

Fig. 2: Source of information

Source of information that statistical (cut-off) method to be used in the tender evaluation: Figure 2 shows the number of contractor who knew the statistical (cut-off) method is to be used in the tender evaluation. 15 contractors cited that they are aware from the use of cut-off method in the evaluation from sources such as the PWD's officer, research, seminars and their colleagues. Ten (10) contractors stated that 
they knew it from the consultants whilst the other six (6) contractors knew it from the tender document. Of the number of contractors being surveyed, (9) contractors said they don't know and two (2) contractors did not answer this question.

Table 2: The strategy of tender price

\begin{tabular}{llc}
\hline No & Strategy & Number of response \\
\hline 1 & $\begin{array}{l}\text { Make sure the rates are } \\
\text { competitive market price }\end{array}$ & 41 \\
2 & $\begin{array}{l}\text { Obtain quotation from sub- } \\
\text { contractor for specialist work }\end{array}$ & 32 \\
3 & $\begin{array}{l}\text { Obtain price from supplier } \\
\text { for special Materials }\end{array}$ & 27 \\
4 & $\begin{array}{l}\text { Ensure that there is no } \\
\text { arithmetical error } \\
5\end{array}$ & $\begin{array}{l}\text { Ensure that the cost/floor } \\
\text { area is acceptable }\end{array}$ \\
\hline
\end{tabular}

The strategy of tender price to ensure that overall pricing is above the cut-off price: The contractors were asked "If you knew that the project to be evaluated using statistical (cut-off) method, how do you strategise your tender pricing to ensure that your overall pricing is above the cut-off price?". As this was a multiplechoice question, most contractors stated that they made sure that the rates were competitive market price. For this purpose the contractors obtained quotations from sub-contractor for specialist works and obtained price from supplier for special materials to strategise the tender price. Other strategies used by the contractors are summarised in Table 2.

Information concerning previous method: The contractors were also asked on the previous method of tender evaluation for projects they have been awarded. The questions were such as;

* In tenders you have been awarded, what do you think was the basis of the award?

* In your opinion, should the award be based solely to the QS estimate?

* Did you have any problem handling the job awarded based on lowest price or based on QS estimate?

* Do you agree that the current market price should be part of the basis in evaluating tender?
* Do you agree if the selection of the contractor based on the most competitive price in the market, this will avoid personally motivated bias in tender reporting?

* Which do you prefer, a tender awarded on the basis of comparison with QS estimate or selected based on statistical method or based on the lowest?

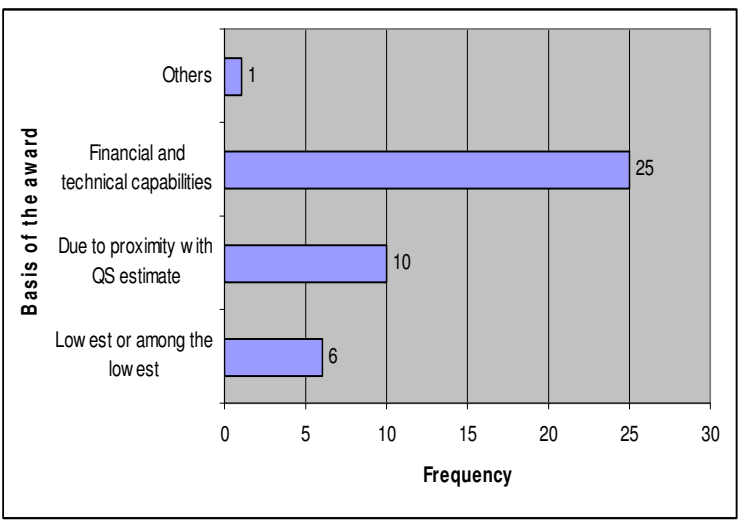

Fig. 3: Basis of the tenders awarded

Basis of the tenders awarded: Figure 3 illustrates that most of the contractors (25) stated that the tenders awarded to them in previous were based on the financial capabilities. Besides that, 10 contractors reported it was due to proximity with QS estimate while only six (6) contractors said that it was based on lowest or among the lowest

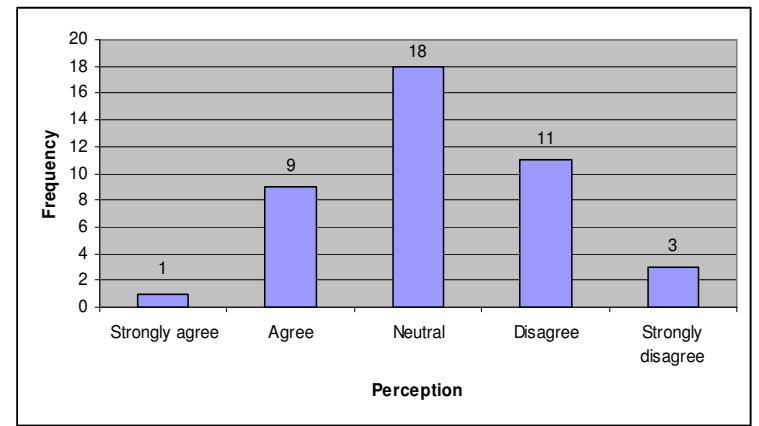

Fig. 4: Perception of the award should be based solely to the QS estimate

Perception of the award should be based solely to the Quantity Surveyor estimate: Figure 4 indicates that 18 contractors seemed to neither agreed nor disagreed that the award should be based solely to the QS estimate. Eleven (11) contractors were more likely to disagree while nine (9) contractors agreed. 


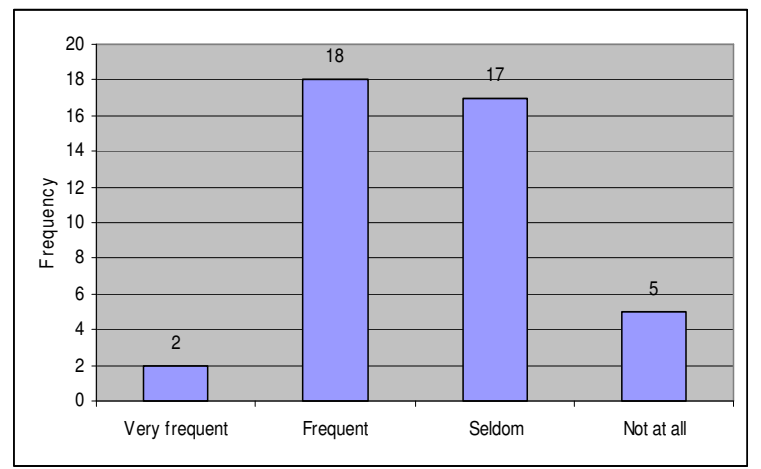

Fig. 5: Problem handling the job awarded based on lowest price or based on QS estimate

Problem handling the job awarded based on lowest price or based on QS estimate: Based on Fig. 5, it reveals that 18 contractors stated they frequently faced problems when handling the job awarded based on lowest price or based on QS estimate. However, 17 contractors reported that they rarely faced problems while 5 contractors stated 'not at all'. Only 2 contractors said they frequently faced problems when handling projects awarded as such. This data clearly indicates that the method of awarding project based on the lowest price or QS estimate is seriously flawed and should be replaced with a more systematic and efficient approach that ensures the price quoted will be based on current market price.

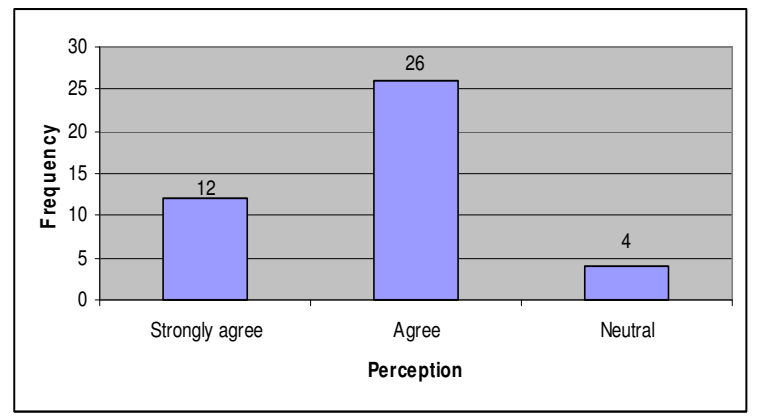

Fig. 6: Perception of the contractor that the current market should be part of the basis in evaluating tender

Perception of the contractor that the current market price should be part of the basis in evaluating tender: As can be clearly seen in Fig. 6, it shows that most of the contractors (26) agreed and 12 contractors strongly agreed that the current price should be part of the basis in evaluating tender. There were four (4) contractors who neither agree nor disagreed towards

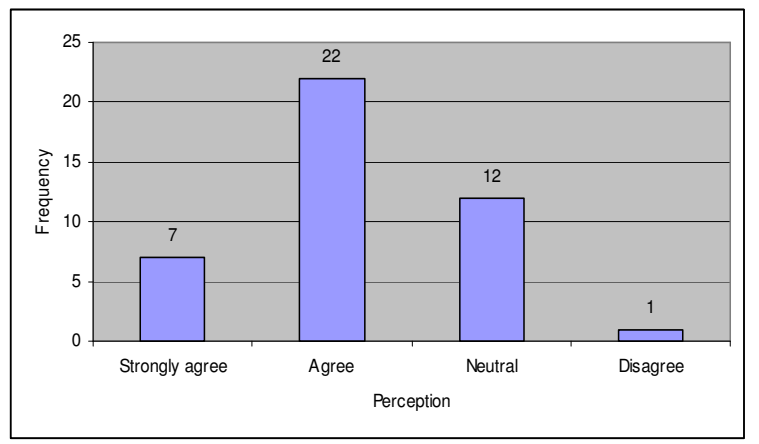

Fig. 7: Perception of the selection of the contractor based on the most competitive price will avoid personally motivated bias in tender report

Perception of the selection of the contractor should be based on the most competitive price will avoid personally motivated bias in tender reporting: As shown in Fig. 7, 22 contractors agreed and 7 contractors strongly agreed that the selection of contractor should be based on the most competitive price and this will avoid personally motivated bias in tender reporting. On the contrary, 12 contractors were neither agreed nor disagreed while only one (1) contractor disagreed with this statement. This result shows that the selection of contractor based on statistical method will avoid personally motivated bias in tendering procedure.

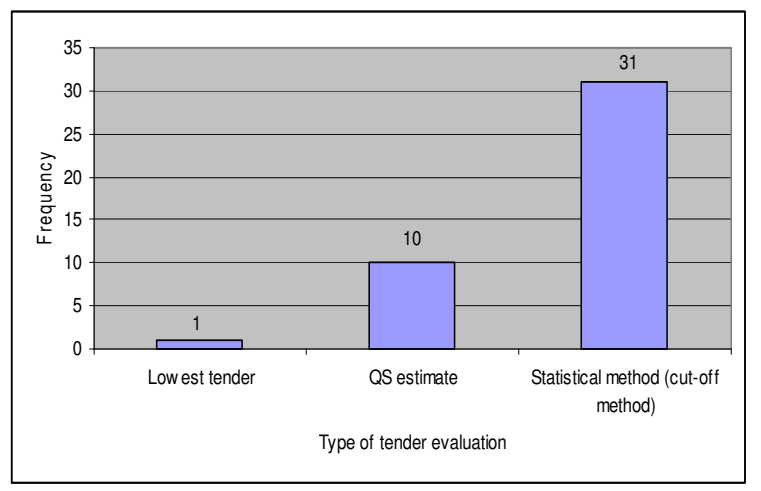

Fig. 8: Preferred method of tender evaluation

Preferred method of tender evaluation: When asked the preferred method of tender evaluation, significantly, majority of the contractors (31) selected the statistical method as compared to QS estimate (10) and lowest tender methods (1) as indicated in Fig. 8. 
Am. J. Appl. Sci., 4 (12): 1084-1089, 2007

Table 3: Result of perception of contractor to the new practice of tender selection using statistical method

\begin{tabular}{|c|c|c|c|c|c|c|}
\hline \multirow{3}{*}{ No } & \multirow{3}{*}{ Statement } & \multicolumn{5}{|c|}{ Number of response } \\
\hline & & 1 & 2 & 3 & 4 & 5 \\
\hline & & Strongly agree & Agree & Neutral & Disagree & Strongly disagree \\
\hline 1 & $\begin{array}{l}\text { The most suitable method to select a } \\
\text { capable contractor based on the current } \\
\text { market price. }\end{array}$ & 7 & 22 & 11 & 2 & 0 \\
\hline 2 & $\begin{array}{l}\text { It can avoid individual decision-making } \\
\text { process that is influenced by personal } \\
\text { preference. }\end{array}$ & 7 & 27 & 7 & 1 & 0 \\
\hline 3 & $\begin{array}{l}\text { The evaluation will not be solely based on } \\
\text { the lowest price for award. }\end{array}$ & 9 & 28 & 5 & 0 & 0 \\
\hline 4 & $\begin{array}{l}\text { The evaluation will be more consistent and } \\
\text { transparent. }\end{array}$ & 3 & 25 & 14 & 0 & 0 \\
\hline 5 & $\begin{array}{l}\text { The method will allow more confidence to } \\
\text { the contractor to tender in project }\end{array}$ & 5 & 24 & 11 & 2 & 0 \\
\hline 6 & $\begin{array}{l}\text { The method will reduce the dependence on } \\
\text { department estimate in the tender } \\
\text { evaluation. }\end{array}$ & 3 & 26 & 11 & 2 & 0 \\
\hline 7 & $\begin{array}{l}\text { PWD has implemented a systematic } \\
\text { approach using statistical method }\end{array}$ & 4 & 20 & 15 & 2 & 1 \\
\hline
\end{tabular}

\begin{tabular}{|c|c|c|c|c|}
\hline No & Statement & Mean score & Perception & $p$-value \\
\hline 1 & $\begin{array}{l}\text { The most suitable method to select a capable contractor based } \\
\text { on the current market price. }\end{array}$ & 2.19 & Agree & 0.000 \\
\hline 2 & $\begin{array}{l}\text { It can avoid individual decision making process which is } \\
\text { influenced by personal preference. }\end{array}$ & 2.05 & Agree & 0.000 \\
\hline 3 & $\begin{array}{l}\text { The evaluation will not be solely based on the lowest price for } \\
\text { award. }\end{array}$ & 1.90 & Agree & 0.000 \\
\hline 4 & The evaluation will be more consistent and transparent. & 2.26 & Agree & 0.000 \\
\hline 5 & $\begin{array}{l}\text { The method will allow more confidence to the contractor to } \\
\text { tender in project }\end{array}$ & 2.24 & Agree & 0.000 \\
\hline 6 & $\begin{array}{l}\text { The method will reduce the dependence on department } \\
\text { estimate in the tender evaluation. }\end{array}$ & 2.29 & Agree & 0.000 \\
\hline 7 & $\begin{array}{l}\text { PWD has implemented a systematic approach using statistical } \\
\text { method }\end{array}$ & 2.43 & Agree & 0.000 \\
\hline
\end{tabular}

Perception of contractor to the new practice of tender selection using statistical method: The contractors were asked to answer a set of questions that were designed to obtain their perceptions towards to the new practice of tender selection using statistical method. The perceptions were measured using a 5Likert scale response format $(1=$ Strongly agree to $5=$ Strongly disagree). Table 3 summarises the result.

Based on Table 3, it shows that most of the contractors in this study agreed to the new practice of tender selection using statistical method. Twenty two (22) contractors or $52.0 \%$ of the contractors agreed that the method is the most suitable method to select a capable contractor based on the current market price. Most contractors (27) or $64.0 \%$ also agreed that the method avoids individual decision-making process that is influenced by personal preference. To substantiate,
$67.0 \%$ of the contractors (28) suggested that the evaluation should not be solely based on the lowest price for award. Also, over half of the contractors perceived that the statistical method will allow them more confidence to tender in projects, reduces the dependence on department estimate in the tender evaluation as well as the evaluation will be more consistent and transparent. Finally, 20 contractors $(48.0 \%)$ agreed that the PWD has implemented a systematic approach using statistical method.

In addition, one-sample $t$-test was conducted to further validate the perception of the contractors to the new practice of tender selection using statistical method. The one-sample $t$-test is used to test whether the mean of a single variable differs from a specified value. Therefore, this study wished to test whether the 
mean score for perception of the contractors were less than 2 (strongly agree and agree). The null hypothesis $\left(H_{0}\right)$ of mean score greater than 3 (neutral, disagree and strongly disagree) will be rejected if the $p$-value of the test is less than 0.05 significance level. Table 4 summarises the result of the one sample $t$-test.

As shown in Table 4, all the p-values are less than 0.05 and thus the null hypothesis was rejected. Therefore, it can be concluded that on the average, all the contractors agreed to the new practice of tender selection using statistical method based on each statement above.

\section{CONCLUSION}

From this result, it is clearly shown that statistically it will be easy to identify the competitiveness of tender among the tender price submitted for the project. This in turn will provide a certain degree of transparency to the tender evaluation process when the optimum tender price will be governed only by the tenders received and not by other parties involved in tender. Subsequently, the selection process becomes more manageable and the evaluation can be concentrated on other criteria such as experience and financial capabilities, etc. when the statistical method is used.

One -sample t-test was conducted to validate the perception of the contractors to the new practice of tender selection using statistical method. From the result it is clearly shown that the p-value is less than0.05 and thus null hypothesis was rejected. Therefore, it can be concluded that on the average, all the contractors agreed to the new practice of tender selection using statistical method.

\section{ACKNOWLEDGEMENT}

The author appreciates the support provided by the main supervisor Ir. Salihuddin Hassim, Associate Professor Ir. Dr. Mohd. Razali Abd. Kadir and Associate Professor Dr. Megat Hamdan Megat Ahmad as a committee member for very helpful supervision of the research of which this report is a part of the compulsory to complete a Master programme in Project Management, University Putra Malaysia.

Much appreciated are the useful contributions of staffs at Public Works Department, Kuala Lumpur for their information regarding tendering procedure and provided their documents and cost data for this research, very helpful staff at Master Builders Association Sdn. Bhd. for giving me opportunity to conducting survey at their seminar and eminent construction managers who participated in the survey. Special thanks for their cooperation in this research.

Last but not least, my beloved family for their support and encouragement to complete this research. Thank you.

\section{REFERENCES}

1. Ibrahim, A.S., 2003.Penggunaan harga tender berdasarkan kaedah statistik di dalam penilaian tender projek JKR. QS National Convention. Sheraton Subang Hotels and Towers, Subang Jaya.

2. Ibrahim, A.S., 2004.Usage and adoption of cut -off price based on statistical method in tender evaluation. Master Builder Association Malaysia.

3. Anita, L. and R. Fellows, 2002. Research Methods for Construction. 2nd Edn. Blackwell Publishing, pp: 96-101.

4. Balnaves, M. and P. Caputi, 2001. Introduction to Quantitative Research Methods. SAGE Publications, pp: 52-83.

5. Beeston, D.T., 1983. Statistical Methods for Building Price Data. E.\& F.N SPON, pp: 50-167.

6. Derek, H.T. Walker, 1997. Choosing Appropriate Research Methodology, pp: 149-159.

7. Drew, D.S. and R.M. Skitmore, 1992. Competitive in bidding: A consultant's perspective, pp: 227247.

8. Jabatan Kerja Raya Malaysia, 2000. Panduan Penilaian Tender - tender Kerja.

9. Nachimias, C.F., 1992. Research Methods in the Social Sciences. New York, St.Martin's Press, pp: 125-130.

10. Newton, 1999. Answer to your data analysis questions. SAGE Publication, pp: 65-68. 